\title{
Interparental Conflicts and the Development of Psychopathology in Adolescents and Young Adults ${ }^{1}$
}

\author{
Olga Melo ${ }^{2}$ \\ Universidade de Trás-os-Montes e \\ Alto Douro, Vila Real, Portugal
}

\author{
Catarina Pinheiro Mota \\ Universidade de Trás-os-Montes e \\ Alto Douro, Vila Real, Portugal \\ Universidade do Porto, Porto, Portugal
}

\begin{abstract}
The objective in this study was to analyze to what extent inter parental conflicts and divorce act as predictors of psychopathological development in young people from intact and divorced families. The participants were 827 Portuguese young people between 13 and 25 years of age. A sociodemographic questionnaire, the Children's Perception of Interparental Conflict Scale and the Brief Symptom Inventory were used. Significant difference in the psychopathology were found with regard to gender, age and family structure. As verified, the intensity and lack of solution of the inter parental conflicts positively predict the development of psychopathology. In conclusion, the children whose parents are separated or divorced perceive the frequency and intensity of inter parental conflicts more highly, but present a higher solution level of the inter parental conflicts and higher psychopathology levels. Nevertheless, the family structure has no moderating effect on the interaction between the inter parental conflicts and the development of pyschopathology.
\end{abstract}

Keywords: attachment behavior, marital conflict, psychopathology

\section{Conflitos Interparentais e o Desenvolvimento de Psicopatologia em Adolescentes e Jovens Adultos}

\begin{abstract}
Resumo: O objetivo deste estudo foi analisar em que medida os conflitos interparentais e o divórcio se apresentam como preditores do desenvolvimento de psicopatologia em jovens de famílias intactas e divorciadas. Participaram 827 jovens portugueses de 13 a 25 anos de idade. Foram utilizados um questionário sociodemográfico, o Children's Perception of Interparental Conflict Scale e o Brief Symptom Inventory. Foram encontradas diferenças significativas da psicopatologia face ao gênero, idade e configuração familiar. Constatou-se que o desenvolvimento de psicopatologia é predito positivamente pela intensidade e falta de resolução dos conflitos interparentais. Concluiu-se que os filhos cujos pais se encontram separados ou divorciados têm maior percepção relativamente à frequência e intensidade de conflitos interparentais, porém apresentam maior nível de resolução dos conflitos interparentais e maiores níveis de psicopatologia. Contudo, a configuração familiar não exerce um efeito moderador na interação entre os conflitos interparentais e o desenvolvimento de psicopatologia.
\end{abstract}

Palavras-chave: comportamento de apego, conflito conjugal, psicopatologia

\section{Conflictos Interparentales y Desarrollo de la Psicopatología en Adolescentes y Jóvenes Adultos}

\begin{abstract}
Resumen: La finalidad de este estudio fue examinar en que medida los conflictos maritales y el divorcio actúan como predictivos de psicopatología en jóvenes de familias tradicionales y divorciadas. Participaron 827 jóvenes portugueses de 13 a 25 anos. Fueron utilizados un cuestionario sociodemográfico, la Children's Perception of Interparental Conflict Scale y el Brief Symptom Inventory. Fueron encontradas diferencias significativas en la psicopatología ante el género, la edad y la configuración familiar. Se constato que el desarrollo de la psicopatología se predice positivamente por la intensidad y la no resolución de los conflictos interparentales. Se concluyó que hijos de padres separados o divorciados tienen mayor percepción de frecuencia y intensidad del conflicto marital, pero muestran mayor nivel de resolucion de los conflictos interparentales y mayores niveles de psicopatología. Sin embargo, la configuración familiar no tiene efecto moderador en la interacción entre el conflicto marital y el desarrollo de la psicopatología.
\end{abstract}

Palabras clave: conducta de apego, conflicto marital, psicopatología

\footnotetext{
1 Support: This research was partially funded by FCT under the project PEst-C/PSI/UI0050/2011 and FEDER funds through the COMPETE program under the project FCOMP-01-0124-FEDER-022714.

2 Correspondence address:

Olga Melo. Departamento de Educação e Psicologia, Universidade de Trás-os-Montes e Alto Douro - UTAD, Quinta dos Prados, Edifício do Complexo Pedagógico, 5000-801. Vila Real, Portugal. E-mail: olga_soaresmelo@hotmail.com
}

According to Bowlby (1969, 1980, 1988) and Ainsworth's (1989) attachment theory, the quality of an individual's primordial relationships, established early on with parental figures, caregivers or other significant figures, is relevant to their physical and emotional development. Throughout the second millennium, an increase in the number of divorces has been witnessed. Thus, leading to the 
growing need of research development in this area, where we can then investigate the implications that can be caused by divorce. Divorce is a likely event in today's family life cycle, impacting its structure and the dynamics between the elements of which it is composed (Cano, Gabarra, Moré, \& Crepaldi, 2009).

Therefore, throughout their development, adolescents not only go through the changes and transformations inherent to adolescence, but can also be faced with changes or alterations in their family structure, such as their parent's divorce. These alterations can trigger significant transformations, with all the events that comprise a separation process, namely the presence of interparental conflicts, which put the family's homeostasis at risk (Amato \& Cheadle, 2008; Storksen, Roysamb, Moum, \& Tambs, 2005). Many times, the existence of a quarrelsome family environment can present itself as a risk factor in the development of problems (both internal and external) in adolescents (Castillo, 2007). Interparental conflicts hold implicit particularities which can decrease the quality level of family operation, especially when they are not resolved and thus limit the opportunity for adolescents to learn how to efficiently resolve problems, or even compromise the development of resolution strategies. Moreover, it also decreases the perception of parental support and communication skills, increases the establishment of dysfunctional ties between adolescents and their parents, and also reduces the possibility of providing adolescents with the understanding of family as a cohesive support system (Unger, Brown, Tressell, \& McLeod, 2000).

The results of the research study performed by García, Marín and Currea (2006), which was made up of a sample of 256 families, formed by parents and adolescent children, between the ages of 12 and 18, with the objective of identifying the characteristics of parental relationships that could be considered predictors in the psychological adjustment of the children. It became evident that the existence of conflict between the couple was associated to the development of internalization problems in the children, such as anxiety and depression as well as externalization problems such as aggressive behavior. On the other hand, Unger et al. (2000), in a study done with a sample of 107 adolescents between the ages of 12 and 18, from divorced as well as intact families, had the objective of studying the family and the influence of interparental conflicts on the psychological adjustment of the children, it was found that interparental conflicts have a very close connection with the depressed state of children belonging not only to divorced but also intact families. According to O'Donnell, Moreau, Cardemil and Pollastri (2010), the development of depressive symptomatology can result from negative alterations to the family environment, which surges from parental conflicts, interacting with the children's pessimistic cognitive style. In children with greater resiliency skills, it has been verified that interparental conflicts have a lower impact. This point was developed by Lemos (2010), who worked with a sample of 63 adolescents between the ages of 13 and 18, all considered to have a delinquent record. A lack of involvement, negligence and weak supervision, as well as interparental conflict, from the part of the parents was noted, all of which can be predicting factors of antisocial behavior and the development of psychopathology. In relation to the presence of interparental conflicts, the adolescents that reported the existence of such conflicts presented higher levels of psychopathology, contrary to the young people that have no perception of there being conflicts between their parents. The emotional differences between the children of separated parents and those from intact homes are not entirely due to divorce, but to the conditions and manner in which the couple manages the separation. In other words, the differences are due to the perception that the children have in relation to the manner in which the divorce process is handled, namely the way in which the couple handles conflicts, which many times is of a destructive nature as well as the social support of the parental figure, which many times after divorce, is greatly reduced (Schick, 2002). Authors such as Mota and Matos (2009) refer to the fact that interparental conflict, more than divorce itself, can predict the quality of development, adaptation and resilience in young people, especially since it has been verified that children of divorced parents, which witnessed high levels of interparental conflict, presented a lower resilience capacity compared to those children from intact families with low levels of interparental conflict. Young adults from intact families that witness high levels of interparental conflict are also not immune from problems, feeling many times involved in the conflicts themselves, which can result in damages to their well-being and the quality of their relationship with their parents, this being true for younger and older children (Amato \& Afifi, 2006). It has also been verified that parents, during conflicts, put more pressure on their daughters to choose sides, which leads to them being more sensitive to interparental conflicts than male children (Amato \& Afifi, 2006). Interparental conflicts which involve physical as well as verbal abuse have negative effects on the emotional, cognitive and social development of the children. Therefore, interparental conflict of a pejorative nature, for the children, should keep in mind the level of the intensity, frequency, content, resolution strategies and the expression of conflict, which can be in an open or hidden manner (Benetti, 2006).

The direct consequences of divorce, in reference to the children's well-being, are not linear and uniform for all young people, especially since other variables seem to be implicated and worsen the effects, such as genetic factors, characteristics of the parents, among others (Lamb, 2010). Research should center itself on the individual or contextual differences that are involved in the separation process and not point to divorce as the principal cause of the lack of emotional and behavioral adjustment in the children. These points will also be considered, keeping in mind the importance of interparental conflict on the development 
of psychopathology. Consequently, the objective of this study is to analyze in what way interparental conflict and divorce present themselves as predictors in the development of psychopathology in young people from intact as well as divorced families. We also look to examine the moderating role of the family configuration in the association between interparental conflicts and the development of psychopathology.

With regard to the hypotheses constructed from the proposed objectives, it was foreseen that there would be significant differences between the variable family configuration, the interparental conflicts perceived by the adolescents and the development of psychopathology. Therefore, it is expected that the adolescents from divorced families present more frequent and intense interparental conflicts, but also more resolution. It is also expected that these adolescents from divorced families present more psychopathological symptomatology. Furthermore, it is expected that the development of psychopathology be predicted by interparental conflicts and also that there is no significant prediction in relation to family configuration. Finally, it is anticipated that family configuration does not play a moderating role in the association between interparental conflict and the development of psychopathology.

\section{Method}

\section{Participants}

The sample was composed by 827 participants, ranging in age between 13 and $25(M=17.17 ; S D=3.28)$, residents in Northern Portugal. In terms of the family configuration, 574 (69.4\%) of the individuals came from married or unmarried intact families, 245 (29.6\%) came from separated or divorced families, while the rest $(n=8 ; 1 \%)$ came from another type of family configuration, such as monoparental families (death of spouse). Out of all the participants, 574 (69.4\%) were female, while 253 (30.6\%) were male. The participants held education levels between the 7th grade and University (Master's degree), denoting secondary school level as the average in relation to academic qualifications $(M=10.70 ; S D=2.14)$.

\section{Instruments}

Sociodemographic Questionnaire. Composed of a series of questions not only related to the age, gender and education level of the respondent but also their family. These questions range from the age, profession and education level of both parents to the current composition of the household and marital status. In the case of the individuals from separated or divorced families, additional questions related to the divorce process were asked, such as which parent left the household; how regularly that parent visits the household; whether or not the parent(s) remarried; if so, whether or not there are children from these new relationships living in the household and, finally, if their parents' divorce process was handled in a friendly manner.

Children's Perception of Interparental Conflict Scale (CPIC). Developed by Grych, Seid and Fincham (1992) and adapted to the adolescents and young adults of the Portuguese population by Moura, Santos and Matos (2006). This is considered a self-report questionnaire whose objective is to evaluate the perception that the adolescents and young adults had in relation to the existence of conflict between parental figures. It is initially composed of a total of 49 items, distributed over nine scales. The present study only used the scale referring to the Properties of Interparental Conflicts, which holds the following dimensions: frequency, intensity and resolution.

The responses were given using a Likert type of scale; where the responses vary between completely disagree to completely agree. The internal consistency analysis showed a Chronbach's alpha value of .93 for the present sample. The alpha values, in relation to the dimensions, were .73 for frequency, .77 for intensity and .78 for resolution. The confirmatory factorial analysis presented the adjustment indexes within the critical values, $\mathrm{CFI}$ above $.90(\mathrm{CFI}=.97)$, as well as the RMR indexes (.030) and RMSEA (.070), with values below (.080) adequate (Byrne, 2006; Fan, Thompson, \& Wang, 1999).

Brief Symptom Inventory (BSI). Developed by Degoratis (1993) and validated for the Portuguese population by Canavarro (1999). It consisted of a self-report instrument, which evaluates psychopathological symptoms on a Likert style scale, varying between 0 (never) and 4 (many times), totaling nine dimensions. In this study only the following three dimensions were used: interpersonal sensitivity, depression and anxiety. The internal consistency analysis showed the Chronbach's alpha value at .97 for the totality of the instrument. In what concerns each of the dimensions, the following alpha values were observed: .83 for Interpersonal Sensitivity, .87 for Depression, and .80 for Anxiety. The confirmatory factorial analysis presented adjustment indexes within the critical values, CFI above $.90(\mathrm{CFI}=.95)$, as well as the RMR indexes (.030) and RMSEA (.060), with values below (.080) adequate (Byrne, 2006; Fan et al., 1999).

\section{Procedure}

Data collection. Educational institutions (secondary schools and universities) in the Northern region of Portugal were selected and the appropriate authorizations for data collection were obtained. The completion of the tasks was performed in classrooms where anonymity, confidentiality and voluntary participation were reinforced and secured. The consent for the use of data was obtained through a consent form, signed by the participants or guardians. Then, we proceeded to the inversion of the self-report questionnaires, in order to avoid bias responses due to the fatigue factor.

Considering this was a transversal study, data collection was performed between December 2011 and May 2012, at six 
secondary schools in the 7th and 12th grades as well as classes at the University of Trás-os-Montes and Alto Douro (UTAD - Portugal), these institutions conceded authorization for data collection and provided a wide range of young people to work with, which in turn provided the study with a significant sample of individuals from divorced families. The researcher was present during the administration of the questionnaires in order to explain the objectives of the study, provide directions, and clarify any doubts that arose during the process.

Data analysis. In reference to the handling of data, the results were coded first and then a data base was elaborated for later analysis using the statistical program SPSS version 17. The variables of each research instrument were categorized, proceeding to the inversion of some items, in accordance with the original authors in the Children's Perception of Interparental Conflict Scale (CPIC). The normality of the data distribution was tested. In order to do so, the KolmogorovSmirnov test was used and then results were interpreted. It is used for large samples with the purpose of analyzing the significance value $(p)$, as well as the following graphs: Histograms, Q-QPlots, Scatterplots and Boxplots, since they provide information about the distribution of data (Pallant, 2001). Also calculated were the measures for skewness and kurtosis of the sample data according to the average, assuming normality every time when the values were understood in their unit interval (-1 and 1) (Maroco, 2007). According to the calculated values, it was confirmed that the sample met the inclusion criteria for normality, and therefore statistical analysis were performed. T-tests were developed in order to test the significant differences according to family configuration, and a differential univariate analysis (ANOVA) was also performed in order to analyze the moderating role of family configuration in the association between interparental conflicts and the development of psychopathology in the children. Lastly, multiple hierarchical regression analyses were performed, in blocks, in order to analyze the predictive effect of gender (block 1 Dummy), family configuration (block 2 Dummy), and interparental conflicts (block 3), in the development of psychopathology.

\section{Ethical Considerations}

All ethical precaution was taken throughout the study. Informed consent was obtained from the institutions where data collection occurred; authorization was also obtained from each participant or legal guardian (in the case of minors). Confidentiality of all data was also secured.

\section{Results}

The presentation of results follows, keeping in consideration the methodology and proposed objectives of the study. Table 1 presents the sociodemographic characterization of the individuals from intact and divorced families.

Table 1

Sociodemographic Characterization of the Individuals From Intact and Divorced Families

\begin{tabular}{|c|c|c|c|c|}
\hline & \multicolumn{2}{|c|}{ Intact families } & \multicolumn{2}{|c|}{ Divorced families } \\
\hline & $n=574(69.4 \%)$ & $M(S D)$ & $n=245(29.6 \%)$ & $M(S D)$ \\
\hline \multicolumn{5}{|l|}{ Gender } \\
\hline Male & $408(71.1 \%)$ & & $85(34.7 \%)$ & \\
\hline Female & $166(28.9 \%)$ & & $160(65.3 \%)$ & \\
\hline Age of adolescents/young adults & & $17.42(3.19)$ & & $16.62(3.43)$ \\
\hline$[13-17]$ & $284(49.5 \%)$ & & $169(69 \%)$ & \\
\hline$[18-22]$ & $254(44.3 \%)$ & & $51(20.8 \%)$ & \\
\hline$[23-25]$ & $36(6.3 \%)$ & & $25(10.2 \%)$ & \\
\hline \multicolumn{5}{|l|}{ Education levels } \\
\hline 7th grade & $180(31.4 \%)$ & & $114(46.5 \%)$ & \\
\hline Secondary school & $131(22.9 \%)$ & & $82(33.5 \%)$ & \\
\hline University & $263(45.7 \%)$ & & $49(20 \%)$ & \\
\hline Father age & & $47.45(6.47)$ & & $45.70(7.44)$ \\
\hline$[22-50]$ & $(70.7 \%)$ & & $192(78.4 \%)$ & \\
\hline$[51-70]$ & $(28.6 \%)$ & & $47(19.2 \%)$ & \\
\hline [71-82] & $(.3 \%)$ & & $1(.4 \%)$ & \\
\hline Mother age & & $44.72(5.99)$ & & $43.03(6.36)$ \\
\hline [27-40] & $138(24 \%)$ & & $94(38.4 \%)$ & \\
\hline$[41-50]$ & $346(60.3 \%)$ & & $125(51 \%)$ & \\
\hline$[51-69]$ & $87(15.2 \%)$ & & $26(10.6 \%)$ & \\
\hline \multicolumn{5}{|l|}{ Father academic qualifications } \\
\hline Low education (6th grade or less) & $337(58.7 \%)$ & & $118(48.2 \%)$ & \\
\hline 7 th grade (from 7 th to 12 th) & $196(34.1 \%)$ & & $99(40.4 \%)$ & \\
\hline University (12th grade or more) & $36(6.3 \%)$ & & $18(7.3 \%)$ & \\
\hline
\end{tabular}

Continue 


\begin{tabular}{|c|c|c|c|}
\hline \multicolumn{4}{|l|}{ Mother academic qualifications } \\
\hline Low education (6th grade or less) & $290(50.5 \%)$ & $86(35.1 \%)$ & \\
\hline 7 th grade (from 7 th to 12 th) & $240(41.8 \%)$ & $122(49.8 \%)$ & \\
\hline University (12th grade or more) & $40(7 \%)$ & $36(14.7 \%)$ & \\
\hline \multicolumn{4}{|l|}{ Father professional status } \\
\hline High & $7(1.2 \%)$ & $0(0 \%)$ & \\
\hline Medium high & $33(5.7 \%)$ & $33(13.5 \%)$ & \\
\hline Medium & $137(23.9 \%)$ & $72(29.4 \%)$ & \\
\hline Medium low & $273(47.6 \%)$ & $85(34.7 \%)$ & \\
\hline Low & $120(20.9 \%)$ & $43(17.6 \%)$ & \\
\hline \multicolumn{4}{|l|}{ Mother professional status } \\
\hline High & $9(1.6 \%)$ & $5(2 \%)$ & \\
\hline Medium high & $34(5.9 \%)$ & $39(15.9 \%)$ & \\
\hline Medium & $78(13.6 \%)$ & $47(19.2 \%)$ & \\
\hline Medium low & $171(29.8 \%)$ & $45(18.4 \%)$ & \\
\hline Low & $278(48.4 \%)$ & $107(43.7 \%)$ & \\
\hline \multicolumn{4}{|l|}{ How long are separated/divorced } \\
\hline 6 months or less & & $6(2.4 \%)$ & \\
\hline From 6 months to 2 years & & $37(15.1 \%)$ & \\
\hline From 2 to 4 years & & $29(11.8 \%)$ & \\
\hline 4 years or more & & $172(70.2 \%)$ & \\
\hline Participant's age when separeted/div & & & $8.44(5.12)$ \\
\hline \multicolumn{4}{|c|}{ Who left home } \\
\hline Mother & & $66(26.9 \%)$ & \\
\hline Father & & $176(71.8 \%)$ & \\
\hline \multicolumn{4}{|l|}{ Went to live with } \\
\hline Mother & & $207(84.5 \%)$ & \\
\hline Father & & $24(9.8 \%)$ & \\
\hline Another person & & $12(4.9 \%)$ & \\
\hline \multicolumn{4}{|l|}{ Any parent reconstitued another family } \\
\hline Yes & & $32(13.1 \%)$ & \\
\hline No & & $211(86.1 \%)$ & \\
\hline \multicolumn{4}{|c|}{ Lives with other brother from father/mother } \\
\hline Yes & & $37(15.1 \%)$ & \\
\hline No & & $206(84.1 \%)$ & \\
\hline \multicolumn{4}{|l|}{ Divorce was friendly } \\
\hline Yes & & $144(58.8 \%)$ & \\
\hline No & & $99(40.4 \%)$ & \\
\hline
\end{tabular}

\section{Differential Analyses of Interparental Conflicts and Psychopathology According to Family Configuration}

To test the differences between Interparental Conflicts and Psychopathology via the variable family configuration, T-tests were performed. In relation to Interparental Conflicts in light of family configuration, the results showed the existence of significant differences in the frequency variables: $t(817)=-8.04, p=.001$; with $95 \%$ CI $[-.79,-.48]$, intensity $t(815)=-11.31, p=.001$; with $95 \%$ CI $[-.93,-.65]$ and resolution $t(533)=-13.76, p=.001$; with $95 \%$ CI $[-1.22,-.91]$. Therefore, it was verified that children of separated or divorced parents indicated the existence of greater frequency and intensity of interparental conflict, compared to children from intact families. The children of separated or divorced families also pointed to a greater resolution of interparental conflicts, compared to those children from intact families (Table 2). Although there is a greater frequency and intensity of interparental conflicts in separated or divorced households, there is also a greater capacity of conflict resolution compared to intact families. In what concerns the presence of Psychopathology in light of family configuration, significant differences were observed between the studied variables, namely Interpersonal Sensitivity: $t(415)=-3.18, p=.002$; with $95 \%$ CI [-.32, -.06], depression $t(414)=-3.03, p=.003$; with $95 \% \mathrm{CI}[-.35,-.08]$, and anxiety $t(393)=-3.208, p=.001$; with $95 \%$ CI $[-.30,-.08]$. In other words, it was found that individuals from separated or divorced families presented greater symptomatology compared to the individuals from intact families (Table 2). 
Table 2

Differential Analyses of Interparental Conflicts and Psychopatology According Family Configuration

\begin{tabular}{|c|c|c|c|c|c|}
\hline & $95 \% \mathrm{CI}$ & $\begin{array}{l}\text { Intact families } \\
\quad(n=574) \\
M(S D) \\
\end{array}$ & $\begin{array}{c}\text { Divorced families } \\
(n=245) \\
M(S D)\end{array}$ & $p$ & $\begin{array}{l}\text { Direction of } \\
\text { the significant } \\
\text { differences }\end{array}$ \\
\hline \multicolumn{6}{|c|}{ Interparental Conflict } \\
\hline Frequency & {$[-.79,-.48]$} & $2.79(1.00)$ & $3.43(1.12)$ & .000 & $1<2$ \\
\hline Intensity & {$[-.93,-.65]$} & $2.66(.90)$ & $3.45(.97)$ & .000 & $1<2$ \\
\hline Resolution & {$[-1.22,-.91]$} & $2.75(1.00)$ & $3.84(1.05)$ & .000 & $1<2$ \\
\hline \multicolumn{6}{|l|}{ BSI } \\
\hline $\begin{array}{l}\text { Interpersonal } \\
\text { sensitivity }\end{array}$ & {$[-.32,-.06]$} & $1.89(.83)$ & $2.08(.94)$ & .027 & $1<2$ \\
\hline Depression & {$[-.35,-.08]$} & $1.95(.85)$ & $2.17(.97)$ & .005 & $1<2$ \\
\hline Anxiety & {$[-.30,-.08]$} & $1.83(.74)$ & $2.02(.83)$ & .000 & $1<2$ \\
\hline
\end{tabular}

Note. BSI = Brief Symptom Inventory.

\section{Prediction of Psychopathology Development by Gender, Family Configuration and Interparental Conflicts}

In order to predict psychopathology, the effects of the gender, family configuration and interparental conflicts variables were tested using a multiple hierarchical regression analysis. With regard to the multiple hierarchical regression analysis, for interpersonal sensitivity (Table 3) three blocks were used. In block 1 we placed gender (Dummy, constructed in order to understand, during regression analysis, which of the two genders would be contributing to the prediction of psychopathology) which had a significant contribution $F(1,822)=15.44, p<.001$, explaining $1.8 \%$ of the total variance $\left(R^{2}=.018\right)$, contributing, individually, with $1.8 \%$ of the model's variance $\left(R^{2}\right.$ change $\left.=.018\right)$. In block 2 we placed family configuration (Dummy) which significantly contributes to the model's variance $F(1,821)=10.03, p<.001$ and explains $3 \%$ of the total variance $\left(R^{2}=.030\right)$, presenting an individual contribution of $1.2 \%\left(R^{2}\right.$ change $\left.=.012\right)$. In block 3 we placed interparental conflicts, which also significantly contributed to the model $F(3,818)=19.14, p<.001$ and explains $9.4 \%$ of the total variance $\left(R^{2}=.094\right)$, presenting an individual contribution of $6.4 \%\left(R^{2}\right.$ change $\left.=.064\right)$. Therefore, after analyzing each one of the variables independently, it was found that three registered a significant contribution, with a total variance of $9.4 \%$. Here we present them by order of importance: intensity of interparental conflicts $(\beta=.184)$; frequency of interparental conflicts $(\beta=.132)$ and gender $(\beta=-.132)$ with the contribution of the female gender (Table 3 ).

Concerning the prediction of depression (Table 4), three blocks were also used. In block 1 we placed gender (Dummy), which had a significant contribution $F(1,822)=16.89$, $p<.001$, explaining $2 \%$ of the total variance $\left(R^{2}=.020\right)$, offering an individual contribution of $2 \%$ of the model's variance $\left(R^{2}\right.$ change $\left.=.020\right)$. In block 2 , family configuration (Dummy) significantly contributed to the model's variance $F(1,821)=13.09 ; p<.001$ and explains $3.6 \%$ of the total variance $\left(R^{2}=.036\right)$, presenting an individual contribution of $1.5 \%$ ( $R^{2}$ change $\left.=.015\right)$. In block 3 , interparental conflicts significantly contributed to the model $F(3,818)=17.49, p<.001$ and explains $9.4 \%$ of the total variance $\left(R^{2}=.094\right)$, presenting an individual contribution of $5.8 \%\left(R^{2}\right.$ change $\left.=.058\right)$. After analyzing the contribution of each one of the variables, it was found that three revealed a significant contribution, with a total variance of $9.4 \%$. Here, we present them in order of importance: gender $(\beta=-.139)$ with the female contribution, frequency of interparental conflicts $(\beta=.165)$ and, lastly, intensity of interparental conflicts $(\beta=.127)$, predicting variables of depression as psychopathological symptomatology (Table 4).

Table 3

Interpersonal Sensivity Multiple Hierarchical Regression

\begin{tabular}{lcccccc}
\hline & $R^{2}$ & $R^{2}$ change & $\mathrm{B}$ & $\mathrm{SE}$ & $\beta$ & \multicolumn{1}{c}{$t$} \\
\hline Block 1 & .018 & .018 & -.248 & .063 & -.132 & -3.958 \\
Block 2 & .030 & .012 & & & & \\
Block 3 & .094 & .064 & & & .000 \\
Frequency & & & .106 & .046 & .132 & 2.318 \\
Intensity & & .160 & .052 & .184 & 3.090 \\
Resolution & & & & & .0021
\end{tabular}

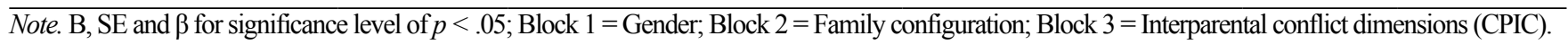


Table 4

Depression Multiple Hierarchical Regression

\begin{tabular}{|c|c|c|c|c|c|c|c|}
\hline & $R^{2}$ & $R^{2}$ change & B & SE & $\beta$ & $t$ & $p$ \\
\hline Block 1 & .020 & .020 & -.270 & .065 & -.139 & -4.148 & .000 \\
\hline Block 2 & .036 & .015 & & & & & \\
\hline Block 3 & .094 & .058 & & & & & \\
\hline Frequency & & & .137 & .047 & .165 & 2.905 & .004 \\
\hline Intensity & & & .115 & .054 & .127 & 2.130 & .033 \\
\hline
\end{tabular}

Note. $\mathrm{B}, \mathrm{SE}$ and $\beta$ for significance level of $p<.05$; Block $1=$ Gender; Block 2 = Family configuration; Block $3=$ Interparental conflict dimensions (CPIC).

In relation to the multiple hierarchical regression analysis regarding anxiety (Table 5), three blocks were also used. In block 1 we placed gender (Dummy), which had a significant contribution $F(1,822)=18.94, p<.001$, explaining $2.3 \%$ of the total variance $\left(R^{2}=.023\right)$, individually contributing with $2.3 \%$ of the model's variance $\left(R^{2}\right.$ change $\left.=.023\right)$. In block 2 , family configuration (Dummy) contributed significantly to the model's variance $F(1,821)=14.83, p<.001$ and explains $4 \%$ of the total variance $\left(R^{2}=.040\right)$, presenting an individual contribution of $1.7 \%$ $\left(R^{2}\right.$ change $\left.=.017\right)$. In block 3 , interparental conflicts significantly contributed to the model $F(3,818)=18.97, p<.001$ and explains $10.2 \%$ of the total variance $\left(R^{2}=.102\right)$, presenting an individual contribution of $6.2 \%\left(R^{2}\right.$ change $\left.=.062\right)$. After analyzing the contribution of each variable, we observed that four presented a significant contribution, with a total variance of $10.2 \%$. Here, we present them in order of importance: intensity of interparental conflicts $(\beta=.182)$, frequency of interparental conflicts $(\beta=.156)$, gender $(\beta=-.150)$ with the female contribution and, finally, conflict resolution $(\beta=-.098)$, predicting variables of anxiety as psychopathological symptomatology (Table 5).

\section{Moderating Role of Family Configuration in the Association Between Interparental Conflicts and the Development of Psychopathology}

Tending to the objectives of the present study, a differential univariate analysis (ANOVA) was performed with the objective of analyzing the moderating role of family configuration in the association between interparental conflicts and the development of psychopathology in children. In what concerns the psychopathological dimensions, no significant interactions were observed with family configuration in the association between interparental conflicts and the development of interpersonal sensitivity $F(2,817)=1.36, p>.05 ; \eta^{2}=.29$; depression $F(2,818)=.35$, $p>.05 ; \eta^{2}=.10$, and anxiety $F(2,817)=.78, p>.05 ; \eta^{2}=.18$. It was found that when faced with high levels of conflict, the individuals presented greater levels of psychopathology, regardless of their family configuration.

\section{Discussion}

The objective of this study was to analyze in what way interparental conflicts and divorce can present themselves as predictors of the development of psychopathology in adolescents and young adults of divorced and intact families. As was expected, differences were observed in relation to interparental conflicts and family configuration. However, the children of divorced or separated parents indicated higher frequency, intensity and resolution of conflicts. The identification of a greater capacity of conflict resolution would be expected after divorce. It was also expected that a lower frequency and intensity of conflict would be found because of the distancing of parents, which was not the case. These results refute those found by Moura and Matos (2008), who analyzed the implications of family configuration and interparental conflict on the attachment between young people and parents. The study was done with the participation of 310 adolescents between the ages of 14 and 18, whose

Table 5

Anxiety Multiple Hierarchical Regression

\begin{tabular}{lccccccc}
\hline & $R^{2}$ & $R^{2}$ change & B & SE & $\beta$ & $t$ \\
\hline Block 1 & .023 & .023 & -.240 & .053 & -.150 & -4.518 \\
Bloco 2 & .040 & .017 & & & & \\
Block 3 & .097 & .062 & & & & \\
Frequency & & & .107 & .039 & .156 & 2.763 \\
Intensity & & .136 & .044 & .182 & 3.076 \\
Resolution & & & -.067 & .033 & -.098 & -1.945 & .006 \\
\hline
\end{tabular}

Note. B, SE and $\beta$ for significance level of $p<.05$; Block $1=$ Gender; Block $2=$ Family configuration; Block $3=$ Interparental conflict dimensions (CPIC). 
parents were divorced. The adolescents described higher levels of conflicts before their parents' divorce. Therefore, it would be expected that the separation or divorce would contribute to a decrease in interparental conflict. However, it is also known that throughout the post-divorce period, many times, the conflicts between parental figures can persist and the decrease of conflict occurs very slowly in a progressive form, conferring a certain stability, concerning the existence of interparental conflicts. According to Cano et al. (2009), the phase after the divorce holds implicit change and difficulty for all members of the family, although, after some time they can profit on an emotional level, being provided with a greater level of maturity, resiliency and better quality of life in general. Even though the conflicts might not cease immediately after divorce, according to Vallejo Orellana, Vallejo and Vallejo (2004), the separation of the couple will trigger, with time, a gradual decrease of interparental conflicts. As stated in the study by Averdijk, Malti, Eisner and Ribeaud (2012), with the objective of analyzing the relationship between parental divorce and the aggressive and internalizing behavior in children and adolescents, it was verified that the interparental conflicts tend to increase during the period around the couple's separation. Although, they are also inclined to decrease drastically through time, being that the effects of divorce on the children are reactive, not lasting through time.

The differential analysis referring to the development of psychopathology, given the family configuration, was found to be significant. Therefore, in agreement with the obtained results, the development of greater levels of psychopathology in young people whose parents are separated or divorced was observed. According to Pratta and Santos (2007), the changes in organization and functioning, which the families can be subjected to throughout their lives, namely due to separation or divorce, can increase the development of psychological problems in the couple's children.

Parental divorce has been connected to the development of a greater negative emotional adjustment in the children, contrary to what is found in the cases of children from intact families (Buehler, Benson, \& Gerard, 2006). However, according to Vallejo Orellana et al. (2004), the effects found in children of separated or divorced parents are not exclusive to divorce itself but also results of the changes and transformations inherent to the separation process, such as a change in residency, which can trigger a cut on a peer level and extend to the entire social network, implicating restructuring skills and adapting to new realities and circumstances.

In the matter of interparental conflicts, it was found that the interparental conflicts, particularly those of elevated frequency and intensity; present themselves as predictors in the development of psychopathological symptomatology in adolescents, such as interpersonal sensitivity, depression and anxiety. Thus, the conflicts may carry the weight of less availability from the part of the parents, being that they are more preoccupied in resolving their own difficulties, they become more irritable and unavailable, which limits their availability to their children. Therefore, due to troublesome family conflicts, in addition to the unavailability of parental figures, the children become vulnerable and susceptible to the development of psychopathological symptomatology. A study by García et al. (2006), which dealt with a sample of 256 families, made up of parents and adolescent children, between the ages of 12 and 18, had the objective of identifying characteristics in the parents' relationship, which could predict the psychological adjustment of their children. The results made it evident that the existence of conflicts between the couple was associated to the development of depressive and anxious symptomatology as well as externalization behavioral problems. In the study performed by Elkington, Bauermeister and Zimmerman (2010), with a sample of 850 African-American adolescents and young adults, the existence of interparental conflicts seemed to be a risk factor in the children's developmental and behavioral process. On the other hand, they stated that a positive presence, in other words, presence, support, emotional exchange and sharing of knowledge by the parental figures in their children's lives, leads to a positive and preventative influence in future behaviors. Following this line of thought, Féres-Carneiro and Diniz Neto (2010) highlight the importance of the couples reducing negativity and promoting positive affection during marital conflict. In addition, the results showed that the perception of a low conflict resolution presents itself as a predictor of anxiety. Therefore, it seems that the parental figures' inability to resolve their own conflicts triggers, in their children, emotional states characterized by high levels of anxiety. According to a study of a sample of 111 couples by Schermerhorn, Chow and Cummings (2010), with the objective of analyzing the influence and interaction of children in the interparental conflicts as well as their effects on the family system, it was found that the exposure and involvement of children in interparental conflict, in the attempt of resolution, can result in negative implications on the children's adjustment. Therefore, children can be involved in these triangles, however, they risk developing maladaptive behaviors, as well as developing internalizing symptomatology such as anxiety and depression.

The obtained results, with the objective of testing the moderating role of family configuration in the association of interparental conflicts and the development of psychopathology, confer the validation of the previous theoretical and empirical assumptions. Thus, in agreement with the results obtained in this study, family configuration does not significantly compromise the development of psychopathology, which means interparental conflicts are better predictors of psychopathology than family configuration. The results corroborate not only the previous hypothesis but also the literature. As stated by Amato and Afifi (2006), the fact that children grow up in intact families, even when there are high levels of conflict between the parents, does not save the children from the effects of interparental conflicts, especially since these conflicts also result in damage to the psychological well-being of the children, regardless of their age.

Interparental conflict can interfere in the intrafamiliar relationships, giving way to a high-tension 
and insecure environment, especially in children (Walper, Kruse, Noack, \& Schwarz, 2005). In this sense, exposing the children to the conflicts between their parents, triggers negative emotional adjustment and leads to the development of depressive symptomatology and a decrease in their psychological well-being, interfering with all parameters of the children's development, whether biological, psychological or even social (Benetti, 2006). Smojver-Azic and Bezinovic's study (2011) had as its objective, the analysis of the influence of family interaction, as protective or risky, against the development of psychopathology in the children, in a sample of 1,191 adolescents, it was found that the quality of the relationships between parental figures seems to influence the psychological adjustment of the adolescents. Therefore, while aggressiveness, hostility and interparental conflict are highlighted as predictors in the development of depressive symptoms, regardless of gender, it was found that cohesive families, and paternal figures which provide experiences guided by cordiality and affection, were presented as significant factors, especially in females. The manner in which parents resolve interparental conflicts should not be neglected, especially since it has been found that even when conflict exists between a couple, the strategies and solutions used by the parents to resolve and overcome conflict, can present themselves as constructive behaviors and positive emotions (Cummings, GoekeMorey, \& Papp, 2004).

\section{Final Considerations}

The family continues to be a relevant and primordial institution, a reference, on which young people base their individual, emotional and relational construction. With the present study, we looked to highlight the effect of interparental conflicts on the development of psychopathology, apart from the family organization and form. The results indicated that the children from separated or divorced families have greater perception of the frequency and intensity of interparental conflict, and adduce, concomitantly, greater resolution of interparental conflicts, compared to the children from intact families. In addition, children from separated or divorced families presented more psychopathological symptoms, compared to those children from intact homes. Finally, the results allow us to conclude that family configuration does not practice a moderating effect on the interaction between interparental conflicts and development of psychopathological symptomatology.

In this sense, the direction of future research could go in search of a longitudinal study, in order to analyze the experience of interparental conflicts and its management in terms of resolution, as well as its relationship concerning psychopathological development. It would be relevant to analyze the time variable of the divorce and whether or not it was litigious or friendly. In this sense, the loyalty conflict variables (coalition and triangulation) could have been added to the study, in order to verify relational contingencies inherent to divorce, and their damage to the mental health of adolescents and young adults. It could also be suggested that there be an analysis of the attachment quality between parents and children as a moderating factor in the association between interparental conflicts and psychopathology. Lastly, we also feel it would be pertinent to use other sources, namely the parents' qualitative perspective regarding the process.

\section{References}

Ainsworth, M. S. (1989). Attachments beyond infancy.American Psychologist, 44(4), 709-716. doi:10.1037/0003-066X.44.4.709

Amato, P. R., \& Afifi, T. D.(2006). Feeling caught between parents: Adult children's relations with parents and subjective well-being. Journal of Marriage and Family, 68(1), 222-235. doi:10.1111/j.1741-3737.2006.00243.x

Amato, P. R., \& Cheadle, J. (2008). Parental divorce, marital conflict and children's behavior problems: A comparison of adopted and biological children. Social Forces, 86(3), 1139-1161. doi:10.1353/sof.0.0025

Averdijk, M., Malti, T., Eisner, M., \& Ribeaud, D. (2012). Parental separation and child aggressive and internalizing behavior: An event history calendar analysis. Child Psychiatric and Human Development, 43(2), 184-200. doi:10.1007/s10578-011-0259-9.

Benetti, S. P. C. (2006). Conflito conjugal: Impacto no desenvolvimento psicológico da criança e do adolescente. Psicologia: Reflexão e Crítica, 19(2), 261-268. doi:10.1590/S0102-79722006000200012

Bowlby, J. (1969). Attachment and loss: Vol.1.Attachment. New York, NY: Basic Books.

Bowlby, J. (1980). Attachment and loss: Vol.3.Loss, sadness and depression. New York, NY: Basic Books.

Bowlby, J. (1988). A secure base: Parent-child attachment and healthy human development. London, United Kingdom: Basic Books.

Buehler, C., Benson, M., \& Gerard, J. M. (2006). Interparental hostility and early adolescent problem behavior: The mediating role of specific aspects of parenting. Journal of Research on Adolescence, 16(2), 265-292. doi:10.1111/j.1532-7795.2006.00132.x

Byrne, B. M. (2006). Structural equation modelling with EQS: Basic concepts, applications, and programming (2nd ed.).Mahwah, NJ: Lawrence Erlbaum.

Canavarro, M., C. (1999). Inventário de sintomas psicopatológicos- BSI. In M. R. Simões, M. Gonçalves, \& L. S. Almeida (Eds.). Testes e provas psicológicas em Portugal (Vol. 2, pp. 87-109). Braga, Portugal: SHO-APPORT. 
Cano, D. S., Gabarra, L. M., Moré, C. O., \& Crepaldi, M. A. (2009). As transições familiares do divórcio ao recasamento no contexto brasileiro. Psicologia: Reflexão e Crítica, 22(2), 214-222. doi:10.1590/S0102-79722009000200007

Castillo, M. A. R. (2007). Los padres y los hijos: Variables de riesgo. Educación y Educadores, 10(1), 27-37.

Cummings, E. M., Goeke-Morey, M. C., \& Papp, L. M. (2004). Everyday marital conflict and child aggression. Journal of Abnormal Child Psychology, 32(2), 191-202. doi:10.1023/B:JACP.0000019770.13216.be

Degoratis, L. (1993). BSI: Brief symptom inventory: Administration, scoring e procedures manual (3rd ed.). Minneapolis, MN: National Computers Systems.

Elkington, K. S., Bauermeister, J. A., \& Zimmerman, M. A. (2011). Do parents and peers matter? A prospective socio-ecological examination of substance use and sexual risk among African American youth. Journal of Adolescence, 34(5), 1035-1047. doi:10.1016/j. adolescence.2010.11.004

Fan, X., Thompson, B., \& Wang, L. (1999). Effects of sample size, estimation methods, and model specification on structural equation modeling fit indexes. Structural Equation Modeling, 6(1), 56-83. doi:10.1080/10705519909540119

Féres-Carneiro, T., \& Diniz Neto, O. (2010). Construção e dissolução da conjugalidade: Padrões relacionais. Paidéia (Ribeirão Preto), 20(46), 269-278. doi:10.1590/S0103-863X2010000200014

García, V. E. C., Marín, I. P. G., \& Currea, F. B. (2006). Relaciones maritales, relaciones paternas y su influencia en el ajuste psicológico de los hijos. Acta Colombiana de Psicología, 9(2), 115-126.

Grych, J., Seid, M., \& Fincham, F. D. (1992). Assessing marital conflict for the child's perspective: The children's perception of interparental conflict scale. Child Development, 63(3), 558-572.

Lamb, M. E. (2010). The role of the father in child development. Hoboken, NJ: John Wiley \& Sons.

Lemos, I. T. (2010). Risco psicossocial e psicopatologia em adolescentes com percurso delinquente. Análise Psicológica, 28(1), 117-132.

Marôco, J. (2007). Análise estatística com utilização do SPSS. Lisboa, Portugal: Edições Sílabo.

Mota, C. P., \& Matos, P. M. (2009). Apego, conflito e auto-estima em adolescentes de famílias intactas e divorciadas. Psicologia: Reflexão e Crítica, 22(3), 344352.doi:10.1590/S0102-79722009000300004

Moura, O., \& Matos, P. M. (2008). Vinculação aos pais, divórcio e conflito interparental em adolescentes. Psicologia, 22(1), 127-152.
Moura, O., Santos, R. A., \& Matos, P.M. (2006, outubro). Children's perception of interparental conflict scale: Análise factorial confirmatória com adolescentes $e$ jovens adultos. Poster presented at the 11th International Conference: Psychological evaluation: Forms and contexts at the University of Minho, Braga, Portugal.

O’Donnell, E. H., Moreau, M., Cardemil, E. V., \& Pollastri, A. (2010). Interparental conflict, parenting, and childhood depression in a diverse urban population: The role of general cognitive style. Journal of Youth and Adolescence, 39(1), 12-22. doi:10.1007/s10964-008-9357-9

Pallant, J. (2001). SPSS survival manual. Buckingham, United Kingdom: Open University Press.

Pratta, E. M. M., \& Santos, M. A. (2007). Família e adolescência: A influência do contexto familiar no desenvolvimento psicológico dos seus membros. Psicologia em Estudo, 12(2), 247-256. doi:10.1590/S1413-73722007000200005

Schermerhorn, A. C., Chow, S. M., \& Cummings, E. M. (2010). Developmental family processes and interparental conflict: Patterns of micro-level influences. Development Psychology, 46(4), 869-885. doi:10.1037/a0019662

Schick, A. (2002). Behavioral and emotional differences between children of divorce and children from intact families: Clinical significance and mediating processes. Swiss Journal of Psychology, 61(1), 5-14. doi:10.1024//1421-0185.61.1.5

Smojver-Azic, S., \& Bezinovic, P. (2011).Sex differences in patterns of relations between family interactions and depressive symptoms in adolescents. Croatian Medical Journal, 52(4), 469-477. doi:10.3325/cmj.2011.52.469.

Storksen, I., Roysamb, E., Moum, T., \& Tambs, K. (2005). Adolescents with a childhood experience of parental divorce: A longitudinal study of mental health and adjustment. Journal of Adolescence, 28(6), 725-739. doi:10.1016/j.adolescence.2005.01.001

Unger, D. G., Brown, M. B., Tressell, P. A., \& McLeod, L. E. (2000). Interparental conflict and adolescent depressed mood: The role of family functioning. Child Psychiatry and Human Development, 31(1), 23-11. doi:10.1023/A:1001922004459

Vallejo Orellana, R., Sanchez-Barranco Vallejo, F., \& Sanchez-Barranco Vallejo, P. (2004). Separación o divórcio: Trastornos psicológicos en los padres y los hijos. RevistaAssociación Espanhola Neuropsiquiatría, 92, 91-110. doi:10.4321/S0211-57352004000400006

Walper, S., Kruse, J., Noack, P., \& Schwarz, B. (2005). Parental separation and adolescents' felt insecurity with mothers: Effects of financial hardship, interparental conflict, and maternal parenting in East and West Germany. Marriage \& Family Review, 36(3-4), 115-145. doi:10.1300/J002v36n03_07 
Olga Melo is a Clinical Psychologist at the Associação Chaves Social IPSS.

Catarina Pinheiro Mota is an Assistant Professor at the Universidade de Trás-os-Montes e Alto Douro, Portugal, and a Researcher - Member of the Centre for Psychology at the Universidade do Porto, Portugal.

Received: Mar. 15, 2013

1st Revision: Oct. 14, 2013

2nd Revision: Apr. 30, 2014

Approved: June 3, 2014

How to cite this article:

Melo, O., \& Mota, C. P. (2014). Interparental conflicts and development of psychopathology in adolescents and young adults. Paidéia (Ribeirão Preto), 24(59), 283-293. doi: 10.1590/1982-43272459201402 


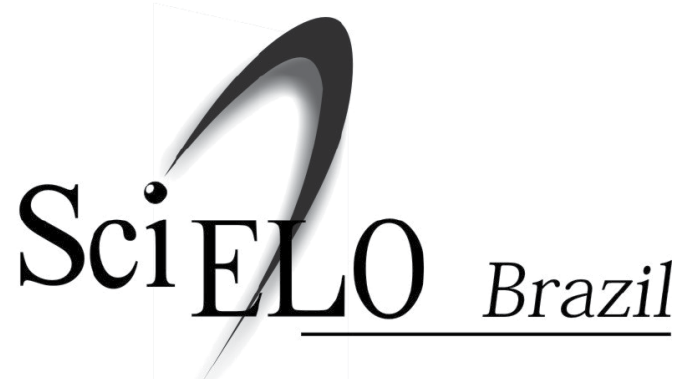

Paidéia (Ribeirão Preto) is a four-monthly publication available in full-text in the Scientific Electronic Library Online - SciELO.

The SciELO interface provides easy access to the tables of content and to the full-text articles.

The SciELO interface also provides the retrieval of articles by the author's name, the words from title, abstract and descriptors, in addition to providing bibliometric indicators and consultation indicators.

The articles are enriched with connections to the LILACS, MEDLINE and PubMed databases.

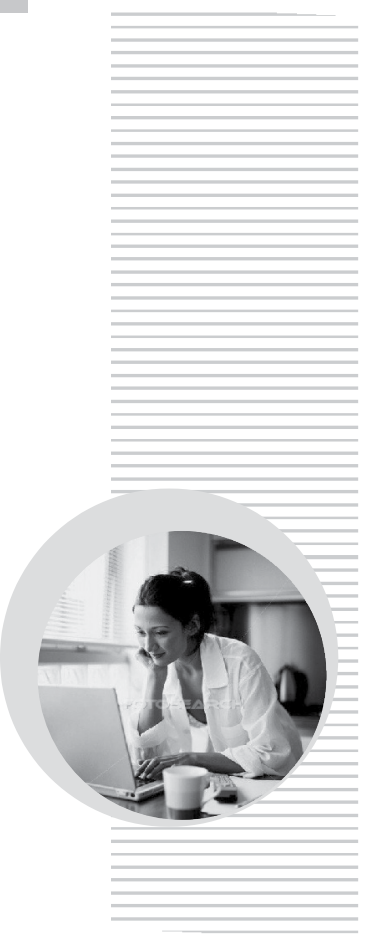

Paidéia (Ribeirão Preto) is a part of SciELO Brazil:

\section{www.scielo.br/paideia}

The SciELO interface provides access to a network of SciELO websites, gathering the major scientific journals of Latin America, Caribbean, Spain, Portugal and South Africa:

\section{www.scielo.org}

The electronic library is a project developed by the São Paulo Research Foundation (FAPESP), in partnership with the Latin American and Caribbean Center on Health Sciences Information (BIREME) and the National Council for Scientific and Technological Development (CNPq). 